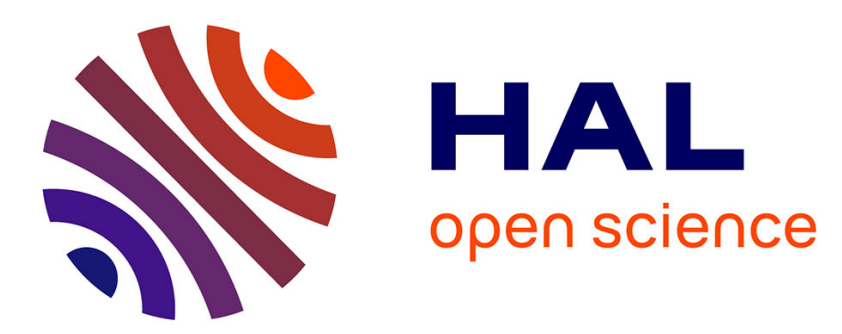

\title{
Impact of nature and length of linker on the catecholase activity of a covalently immobilized copper(II) complex in continuous flow catalysis
}

Ronan Marion, Gopinathan Muthusamy, Florence Geneste

\section{- To cite this version:}

Ronan Marion, Gopinathan Muthusamy, Florence Geneste. Impact of nature and length of linker on the catecholase activity of a covalently immobilized copper(II) complex in continuous flow catalysis. Journal of Molecular Catalysis A: Chemical, 2013, 377, pp.51-56. 10.1016/j.molcata.2013.04.027 . hal-00841742

HAL Id: hal-00841742

https://hal-univ-rennes1.archives-ouvertes.fr/hal-00841742

Submitted on 17 Jul 2013

HAL is a multi-disciplinary open access archive for the deposit and dissemination of scientific research documents, whether they are published or not. The documents may come from teaching and research institutions in France or abroad, or from public or private research centers.
L'archive ouverte pluridisciplinaire HAL, est destinée au dépôt et à la diffusion de documents scientifiques de niveau recherche, publiés ou non, émanant des établissements d'enseignement et de recherche français ou étrangers, des laboratoires publics ou privés. 
Impact of nature and length of linker on the catecholase activity of a covalently immobilized copper(II) complex in continuous flow catalysis

Ronan Marion, Gopinathan Muthusamy, Florence Geneste*

Université de Rennes 1, UMR-CNRS 6226, Laboratoire des Sciences Chimiques de Rennes, Equipe Matière Condensée et Systèmes Electroactifs, Campus de Beaulieu, 35042 Rennes cedex, France

\begin{abstract}
The catecholase activity of four immobilized mononuclear copper(II) catalysts with chains of different nature and length used as linkers is studied in continuous flow catalysis. The graphite felt support was first derivatized by cathodic reduction of 4-carboxymethylbenzenediazonium salts. Complexes with different chains were then covalently immobilized on the functionalized porous support by esterification reaction. The successful achievement of the immobilization process is attested by the presence of the $\mathrm{Cu}^{\mathrm{II} / \mathrm{I}}$ reversible system in cyclic voltammetry. Volume concentrations around $10^{-8} \mathrm{~mol} \mathrm{~cm}^{-3}$ of immobilized catalysts are estimated by integration of the redox peak. Comparison of the catecholase activity of the immobilized complexes allows to conclude on the effect of the chain nature and length. First, high chain length positively influences the catalytic activity. Second, the presence of oxygen atoms in the linker significantly enhances the catecholase activity of the catalyst. A possible explanation is the chain hydrophilicity, making easier the access of the catalytic center by $\mathrm{H}_{2} \mathrm{O}$ molecules.
\end{abstract}

Keywords: catecholase activity, flow, homogeneous supported catalysis, linker, copper complexes

\title{
1. Introduction
}

Copper metalloproteins have been the subject of many investigations due to their catalytic activity and their ability to reversibly bind and activate dioxygen $[1,2]$. Among them, type 3

\footnotetext{
${ }^{*}$ Corresponding author. Tel.: +33 223235965; fax: +33 223235967. E-mail addresse:
} Florence.Geneste@univ-rennes1.fr (F. Geneste) 
proteins are composed of two close copper atoms, each coordinated by three histidine residues. The most known are hemocyanin, tyrosinase and catechol oxidase. Whereas hemocyanin is used to transport and stock dioxygen, tyrosinase catalyses ortho-hydroxylation of phenol and their subsequent oxidation into o-quinones. Catechol oxydase does not have hydroxylation activity but catalyzes the oxidation of $o$-diphenols into $o$-quinones by dioxygen reduction. Many mono and dinuclear copper complexes have been synthesized as biomimetic models for a better mechanistic understanding of the enzyme catalytic process and to find new catalysts for oxidation reactions [3-5]. However, these molecular catalysts are often less stable and selective than the enzyme, whose active site is isolated in a protein backbone. Thus, catalysts have been immobilized on supports to more precisely mimic natural enzymes and to improve their catalytic performances [6-16]. The aim is to provide proper geometry and distance for catalytic centers and to improve the catalyst stability, reducing the possibility of side reactions to occur.

In supported catalysis, several factors influence the activity, such as the nature of the support, the catalyst density, the point of catalyst attachment and the length and nature of the linker. Many studies have shown that increasing the length and the flexibility of the linker facilitates the access of reagents to the catalytic site and enhances the catalytic activity $[17,18]$. Thus, long spacer chains have shown activity approaching that of the corresponding nonimmobilized catalysts. However, in some cases, too long arms can change the catalyst environment and reduce the catalytic activity. Thus, it has been reported that catalyst site isolation is preferentially obtained with chain of intermediate length, whereas long spacer chains led to interactions between two immobilized catalysts [19, 20] or to different coordination modes [21]. Clearly the effect of the linker on the catalytic activity is difficult to generalize.

We have previously reported the covalent immobilization of a mononuclear copper complex based on tripodal ligands on graphite felt and its catecholase activity in continuous flow catalysis [22]. Comparison with results obtained when the catalyst is in solution, underlined the interest of the flow system that gives better conversion yields with using less catalyst. Moreover, with the same catechol concentration and ratio catalyst/substrate, supported catalysis exhibited better results than unsupported one.

In this work, copper complexes with different arms containing an alcohol ending group were immobilized on graphite felt and characterized by cyclic voltammetry. We report the effect of 
the chain nature and length on the catecholase activity and stability of the immobilized catalyst.

\section{Experimental section}

\subsection{Reagents and materials}

Graphite felt was obtained from Le Carbone Lorraine (RVG 4000). All commercially available reagents were used as supplied. All solvents were analytical grade. Tetrahydrofuran (THF) was distilled from deep blue solutions of sodium/benzophenone ketyl prior to use. Syntheses of the tripodal ligands $\mathbf{L}_{\mathbf{1}}-\mathbf{L}_{\mathbf{3}}$ and the corresponding copper complexes 1-3 have been previously described [23]. 4-carboxymethyl-benzenediazonium salts was prepared according to literature and stored under argon in a freezer [24]. The covalent immobilization of the complexes was performed according to a previously described procedure [22].

\subsection{Instrumentation}

Voltammetric experiments were carried out using an EDAQ potentiostat unit, with the EChem software package. A platinum wire working electrode, a platinum wire auxiliary electrode, and a saturated calomel reference electrode were used in a standard three-electrode configuration. The graphite felt sample $\left(1 \mathrm{~cm}^{3}\right)$ was mechanically fixed to the platinum wire before analysis by inserting the wire directly into the felt. Cyclic voltammetry analyses of immobilized complexes were performed in acetonitrile containing 0.1 M_tetrabutylammonium hexafluorophosphate, under a dinitrogen atmosphere.

\subsection{Synthesis}

2-\{2-[2-(2-Amino-ethoxy)-ethoxy]-ethoxy\}-ethanol $\mathbf{6}$ was prepared from tetra(ethyleneglycol) $\mathbf{5}$ according to a procedure described in literature [25].

2-(2-\{2-[2-(Bis-pyrazol-1-ylmethyl-amino)-ethoxy]-ethoxy\}-ethoxy)-ethanol L4. A mixture of 1-hydroxymethylpyrazole (51 mg, $0.52 \mathrm{mmol})$ and 2-\{2-[2-(2-Amino-ethoxy)-ethoxy]ethoxy\}-ethanol $(50 \mathrm{mg}, 0.26 \mathrm{mmol})$ was stirred without solvent for $3 \mathrm{~h}$ at $70{ }^{\circ} \mathrm{C}$ under vacuum (1 mbar). The product was obtained as a yellow oil in quantitative yield. ${ }^{1} \mathrm{H}$ NMR $\left(400 \mathrm{MHz}, \mathrm{CDCl}_{3}\right): \delta 7.55(\mathrm{~d}, J=3.2 \mathrm{~Hz}, 2 \mathrm{H}) ; 7.46(\mathrm{~d}, J=2.4 \mathrm{~Hz}, 2 \mathrm{H}) ; 6.21(\mathrm{dd}, J=2.4 \mathrm{~Hz}$, 
$J=3.2 \mathrm{~Hz}, 2 \mathrm{H}) ; 5.06(\mathrm{~s}, 4 \mathrm{H}) ; 3.65-3.45(\mathrm{~m}, 14 \mathrm{H}) ; 2.85(\mathrm{t}, J=7.0 \mathrm{~Hz}, 2 \mathrm{H}){ }^{13} \mathrm{C} \mathrm{NMR}(100$ $\left.\mathrm{MHz}_{\mathrm{CDCl}}\right): \delta 139.6 ; 130.1 ; 105.8 ; 72.6 ; 70.6 ; 70.5 ; 70.4 ; 70.3 ; 70.2 ; 68.4 ; 61.6 ; 49.5$. HRMS (ESI): $m / z$ calcd for $\mathrm{C}_{16} \mathrm{H}_{27} \mathrm{~N}_{5} \mathrm{O}_{4} \mathrm{Na}[\mathrm{M}+\mathrm{Na}]^{+}: 376.19607$; found, 376.1956

Copper complex 4. Copper(II) chloride ( $35 \mathrm{mg}, 0.26 \mathrm{mmol}$ ) and tripodal ligand (92 mg, 0.26 mmol) were stirred in anhydrous THF for $2 \mathrm{~h}$ at room temperature. The solvent was evaporated. The complex was washed with a small amount of THF and dried under vacuum. Yield 0,09 g (72\%) of a green compound. HRMS (ESI): $m / z$ calcd for $\mathrm{C}_{16} \mathrm{H}_{27} \mathrm{~N}_{5} \mathrm{O}_{4} \mathrm{ClCu}$ [M$\mathrm{Cl}]^{+}:$451.1047; found, 451.1047

\subsection{Immobilization of copper complexes on graphite felt}

$100 \mathrm{mg}$ of 4-carboxymethyl-benzenediazonium salts, dissolved in $100 \mathrm{~mL}$ of degassed $\mathrm{H}_{2} \mathrm{SO}_{4}$ were reduced at $-0.2 \mathrm{~V}_{\mathrm{SCE}}$ for $5 \mathrm{~min}$ under nitrogen, using a graphite felt (48 mm diameter, 12 $\mathrm{mm}$ thickness) as working-electrode. Then the derivatized graphite felt was ultrasonicated 4 times in deionized water for $15 \mathrm{~min}$ and dried under vacuum. The functionalized graphite felt was placed in $50 \mathrm{~mL}$ anhydrous dichloromethane in a reactor under argon at $0{ }^{\circ} \mathrm{C} .0 .5 \mathrm{~mL}$ of diethylaminosulfur trifluoride (DAST) were added and the solution was stirred at room temperature for $5 \mathrm{~h}$. The felt was ultrasonicated two times in dichloromethane. Then, the electrode was placed in a solution of anhydrous dichloromethane, $1 \mathrm{~mL}$ of triethylamine and $100 \mathrm{mg}$ of copper complex. The solution was stirred at room temperature for 1 day. The modified electrode was ultrasonicated two times in dichloromethane and two times with acetone for $15 \mathrm{~min}$.

\subsection{Catalysis}

Heterogeneous catalysis was performed in a flow cell [22] containing the modified graphite felt (10 mm diameter, $12 \mathrm{~mm}$ thickness). A fresh solution of $8.7 \times 10^{-3} \mathrm{~mol} \mathrm{~L}^{-1}$ of 3,5-di-tertbutylcatechol in methanol maintained in air $\left(\mathrm{O}_{2}\right.$ from air was used as oxidant $)$ at constant stirring and temperature of $25{ }^{\circ} \mathrm{C}$ percolated the porous support with a constant flow rate (3 $\mathrm{mL} \min ^{-1}$ ) monitored by a Gilson minipuls 2 peristaltic pump. The number of moles of catalyst was determined by cyclic voltammetry for a graphite felt of $10 \mathrm{~mm}$ diameter and 12 $\mathrm{mm}$ thickness. To compare the 4 immobilized catalysts, the same ratio of catalyst/substrate $\left(4.5 \times 10^{-5}\right)$ was used for all experiments, by adjusting the volume of the solution of 3,5-ditert-butylcatechol. Since 3,5-di-tert-butylquinone gives a strong absorption band at $400 \mathrm{~nm}$ in 
methanol, the absorbance was continually monitored at $400 \mathrm{~nm}$ for $1 \mathrm{~h}$ using a dipping probe colorimeter to follow the reaction.

\section{Results and discussion}

\subsection{Synthesis of the complexes}

Four copper complexes 1-4 containing tripodal ligands with pyrazole rings $\mathbf{L}_{\mathbf{1}}-\mathbf{L}_{\mathbf{4}}$ with different nature and length chains were studied (Fig. 1). The linker was directly incorporated in the complex structure to minimize the number of steps of the immobilization process that are usually not quantitative because of the heterogeneous reaction medium and steric hindrance.

Figure 1

The complexes 1-3 were synthesized according to previously reported procedures [23]. Complex $\mathbf{4}$ was prepared by reaction of the ligand $\mathbf{L}_{\mathbf{4}}$ with $\mathrm{CuCl}_{2} . \mathbf{L}_{\mathbf{4}}$ was synthesized in 5 steps from 2-\{2-[2-(2-Hydroxy-ethoxy)-ethoxy]-ethoxy $\}$-ethanol 5 (Scheme 1).

\section{Scheme 1}

After monotosylation of the diol $\mathbf{5}$ and subsequent substitution reaction by sodium azide, reduction of the azido group by triphenylphosphine afforded the aminoalcohol 6. A condensation reaction of 1-hydroxypyrazole on 6 performed at $70{ }^{\circ} \mathrm{C}$ for $3 \mathrm{~h}$ without solvent led to the ligand $\mathbf{L}_{\mathbf{4}}$ with the oxoethylene arm. The corresponding copper complex was prepared in anhydrous tetrahydrofuran at room temperature for $2 \mathrm{~h}$ with $\mathrm{CuCl}_{2}$ and conserved under argon.

\subsection{Immobilization of the complexes on graphite felt}

The graphite felt electrode was first derivatized by cathodic reduction of 4-carboxymethylbenzenediazonium salts 6 at $-0.2 \mathrm{~V}_{\mathrm{SCE}}$ in $0.5 \mathrm{M} \mathrm{H}_{2} \mathrm{SO}_{4}$ for 5 min in a flow cell (Scheme 2) [23].

Scheme 2 
The passivation of the graphite fibers modified with aryl diazonium salts was investigated by cyclic voltammetry using potassium ferricyanide as a redox probe. Fig. 2 shows a cyclic voltammogram of potassium ferricyanide before and after modification with 4carboxymethyl-benzenediazonium salts 6 in a $0.05 \mathrm{M}$ phosphate buffer $\mathrm{pH} 7.0$ at a scan rate of $0.1 \mathrm{~V} \mathrm{~s}^{-1}$.

Figure 2

After the modification of the surface with the aryl diazonium salts, the redox peaks of ferricyanide observed with fresh graphite felt almost disappeared. This blocking effect confirms the presence of a molecular layer on the graphite fibers.

The functionalized surface was then allowed to react with DAST and then with the complexes 1-4. DAST was chosen as coupling agent since acid fluorides are not very sensitive to moisture, avoiding the use of drastic anhydrous conditions. The immobilized complexes were analyzed by cyclic voltammetry in acetonitrile (Fig. 3).

Figure 3

They exhibited a quasi-reversible system corresponding to the $\mathrm{Cu}^{\mathrm{II/I}}$ couple. The half-wave potentials are anodically shifted compared with the same complexes in solution (Table 1).

\section{Table 1}

This phenomenon can be linked to the coordination mode of the metal, which can be different in solution than when it is immobilized. For example, the alcohol ending group of the complexes can be coordinated to the metal in solution [26], whereas in heterogeneous conditions it is involved in an ester bond. It is interesting to note that the difference in halfwave potential between complexes $\mathbf{3}$ and $\mathbf{4}$ containing oxoethylene units and $\mathbf{1}$ and $\mathbf{2}$ is more significant for grafted complexes (up to $100 \mathrm{mV}$ ) than in solution (up to $30 \mathrm{mV}$ ).

The volume concentrations $\Gamma$ of immobilized complexes were estimated from integration of the $\mathrm{Cu}^{\mathrm{II} / \mathrm{I}}$ systems by using the Faraday law (Fig. 1 and Table 1). The values are in the same range for the four complexes with relatively better results for complexes $\mathbf{1}$ and $\mathbf{2}$ containing alkyl arms. 


\subsection{Catalysis}

The catecholase activity of the immobilized copper(II) complexes was examined by testing their ability to catalyze 3,5-di-tert-butylcatechol in a flow cell [22]. This substrate has been widely used for catecholase activity study due to its low potential for the quinone-catechol couple, leading to easy oxidation to the corresponding quinone and to its bulky substituents limiting the degradation of the substrate for at least $6 \mathrm{~h}$. A peristaltic pump was used to flow the solution with the substrate through the catalyst-containing porous support at constant flow rate. The kinetics of formation of 3,5-di-tert-butylquinone in the presence of the catalyst was continually monitored using a dipping probe colorimeter, by using the absorption band of the quinone at $400 \mathrm{~nm}$. The reaction was performed for $1 \mathrm{~h}$ at constant agitation and temperature of $25{ }^{\circ} \mathrm{C}$ and with a catalyst/substrate ratio of $4.5 \times 10^{-5}$. These conditions correspond to the beginning of the conversion of catechol into quinone. Since the volume concentrations of grafted catalysts 1-4 are slightly different (Table 1), the volume of methanol was adjusted so that the catechol concentration in solution remained the same, allowing the kinetic comparison of the reaction conducted with the four catalysts. A blank was also carried out with a graphite felt only modified by the diazonium salt. The results are given in Fig. 4.

Figure 4

The rates were determined from the slope of the tangent to the absorbance versus time curve (Table 2).

Table 2

The curve of the complex 4 is nonlinear after $30 \mathrm{~min}$. This phenomenon can be explained by a degradation of the catalyst during the oxidation reaction. For this reason, the rate of $\mathbf{4}$ was only determined for the first 30 minutes.

The catalytic activity of the graphite felts containing the copper complexes is significantly higher than the blank, showing that all the catalysts are still active when they are immobilized. Comparison of complexes with chains of the same nature (1 and $2 ; \mathbf{3}$ and $\mathbf{4}$ ) highlighted the effect of increased chain length on the catalytic activity. This phenomenon is often observed 
in homogeneous supported catalysis and is due to an increase of the chain flexibility, facilitating the approach of the substrate to the catalytic center [27, 28].

Interestingly, complexes $\mathbf{3}$ and $\mathbf{4}$ containing oxoethylene units in their chain exhibited the highest activities. Since electrochemical analyses showed higher half-wave potentials for the immobilized complexes 3 and $\mathbf{4}$ than $\mathbf{1}$ and $\mathbf{2}$ (Table 1), the presence of an oxygen atom in the chain seems to decrease the electronic density on the metal. Such a decrease of the electronic density will make easier the reduction of the $\mathrm{Cu}^{\mathrm{II}}$ intermediate formed in the catalytic cycle in $\mathrm{Cu}^{\mathrm{I}}$, enhancing the catalytic activity (Scheme 3) [23]. This effect is different than in solution, where the presence of an oxygen atom in the third position of the carbon chain have led to a decrease of the catalytic activity, attributed to the coordination of the oxygen atom to the metal [23]. When the complex is immobilized, the lack of chain mobility probably prevents the coordination of the oxygen atom to copper. Since the catalytic process requires the intervention of water, another parameter that would enhance the catalytic activity would be the hydrophilicity of chains containing oxoethylene units. The presence of this chain would help $\mathrm{H}_{2} \mathrm{O}$ molecules to reach the active site (Scheme 3).

\subsection{Stability}

Since complex 4 seems to show degradation after $30 \mathrm{~min}$ of catalysis (Fig. 4), we tested the air-stability of the catalysts. Copper complexes 2-4 were analyzed by cyclic voltammetry after several days exposure to air. For $\mathbf{2}$ and $\mathbf{3}$, the voltammograms exhibited a slight decrease of the currents with a cathodic shift (around $200 \mathrm{mV}$ ) of the half-wave potentials, as exemplified in Fig. 1. With 4, the voltammogram remained identical. When the catalyst-modified felts were maintained under argon, no difference was observed in cyclic voltammetry. These results show that the grafted complexes $\mathbf{2}$ and $\mathbf{3}$ evolved in time when exposed to air.

The catecholase activity of the immobilized complexes was also tested after air-exposition. A significant decrease of the activity was observed for complexes $\mathbf{2}$ and $\mathbf{3}$, whereas no evolution was noticeable when the oxidation reaction was conducted with immobilized catalyst $\mathbf{4}$ after 10 days at air (Fig. 5).

Figure 5

The lack of air-stability of immobilized complexes $\mathbf{2}$ and $\mathbf{3}$ is not clear at the moment, and their catalytic activity as for all the complexes was tested immediately after their preparation. 
Thus, the discrepancy of the catalytic activity of $\mathbf{4}$ after $30 \mathrm{~min}$ of catalysis is not due to instability at air since $\mathbf{4}$ is more air-stable than its analogues $\mathbf{2}$ and $\mathbf{3}$. It can be attributed to the degradation of the catalyst during the catalytic cycle when it is in an intermediate form.

\section{Conclusion}

Four copper(II) complexes with chains of different nature and length were immobilized on a porous carbon support functionalized by electrochemical reduction of diazonium salts. They were characterized by cyclic voltammetry, showing a good covering of all the graphite fibers with volume concentrations of grafted catalysts around $10^{-8} \mathrm{~mol} \mathrm{~cm}^{-3}$. The catecholase activity of the complexes was then investigated in continuous flow catalysis. Better results were obtained with immobilized complexes than with graphite felt modified by cathodic reduction of 4-carboxymethyl-benzenediazonium salts, used as a reference. This underlines that all the complexes are still catalytically active when they are immobilized. Comparison of the catalytic activity of the four complexes highlighted two phenomenons. First, high chain lengths enhance the catalytic activity due to their flexibility, making easier the substrate approach. A second effect, even more pronounced, is the nature of the chain. Better results were achieved with chains containing oxoethylene units. Two possible explanations were proposed here.

\section{References}

[1] K. D. Karlin, Science 261 (1993) 701-708.

[2] E. I. Solomon, U. M. Sundaram, T. E. Machonkin, Chem. Rev. 96 (1996) 2563-2605.

[3] E. A. Lewis, W. B. Tolman, Chem. Rev. 104 (2004) 1047-1076.

[4] K. A. Magnus, H. Tonthat, J. E. Carpenter, Chem. Rev. 94 (1994) 727-735.

[5] L. M. Mirica, X. Ottenwaelder, T. D. P. Stack, Chem. Rev. 104 (2004) 1013-1045.

[6] M. A. Bizeto, W. A. Alves, C. A. S. Barbosa, A. Ferreira, V. R. L. Constantino, Inorg. Chem. 45 (2006) 6214-6221.

[7] I. U. Castro, D. C. Sherrington, A. Fortuny, A. Fabregat, F. Stuber, J. Font, C. Bengoa, Catal. Today 157 (2010) 66-70.

[8] S. Chavan, D. Srinivas, P. Ratnasamy, J. Catal. 192 (2000) 286-295.

[9] B. Dutta, S. Jana, R. Bera, P. K. Saha, S. Koner, Appl. Cat. A: Gen. 318 (2007) 89-94.

[10] G. Grigoropoulou, K. C. Christoforidis, M. Louloudi, Y. Deligiannakis, Langmuir 23 (2007) 10407-10418. 
[11] M. Louloudi, K. Mitopoulou, E. Evaggelou, Y. Deligiannakis, N. Hadjiliadis, J. Mol. Catal. A: Chem. 198 (2003) 231-240.

[12] M. Mureseanu, V. Parvulescu, R. Ene, N. Cioatera, T. D. Pasatoiu, M. Andruh, J. Mater. Sci. 44 (2009) 6795-6804.

[13] P. K. Saha, B. Dutta, S. Jana, R. Bera, S. Saha, K. Okamoto, S. Koner, Polyhedron 26 (2007) 563-571.

[14] S. Striegler, M. G. Gichinga, M. Dittelt, Org. Lett. 10 (2008) 241-244.

[15] S. Seelan, A. K. Sinha, Appl. Cat. A: Gen. 238 (2003) 201-209.

[16] D. Zois, C. Vartzouma, Y. Deligiannakis, N. Hadjiliadis, L. Casella, E. Monzani, M. Louloudi, J. Mol. Catal. A: Chem. 261 (2007) 306-317.

[17] W. Zhou, D. He, Chem. Commun. (2008) 5839-5841.

[18] E. Lindner, A. Jäger, F. Auer, W. Wielandt, P. Wegner, J. Mol. Catal. A: Chem. 129 (1998) 91-95.

[19] N. Madhavan, C. W. Jones, M. Weck, Acc. Chem. Res. 41 (2008) 1153-1165.

[20] X. L. Zheng, C. W. Jones, M. Weck, Adv. Synth. Catal. 350 (2008) 255-261.

[21] A. L. Faria, T. C. O. Mac Leod, M. D. Assis, Catal. Today 133 (2008) 863-869.

[22] R. Marion, G. Muthusamy, F. Geneste, J. Cat. 286 (2012) 266-272.

[23] R. Marion, M. Zaarour, N. A. Qachachi, N. M. Saleh, F. Justaud, D. Floner, O. Lavastre, F. Geneste, J. Inorg. Biochem. 105 (2011) 1391-1397.

[24] C. Bourdillon, M. Delamar, C. Demaille, R. Hitmi, J. Moiroux, J. Pinson, J. Electroanal. Chem. 336 (1992) 113-123.

[25] M. S. Cubberley, B. L. I. Iverson, J. Am. Chem. Soc. 123 (2001) 7560-7563.

[26] M. El Kodadi, M. Fouad, A. Ramdani, D. Eddike, M. Tillard, C. Belin, Acta Cryst. E60 (2004) m426-m428.

[27] W. Zhou, Y. M. Li, D. H. He, Appl. Cat. A: Gen. 377 (2010) 114-120.

[28] H. Molinari, F. Montanari, P. Tundo, Chem. Commun. (1977) 639-641.

Table 1 : Electrochemical data of the immobilized copper(II) complexes 1-4

\begin{tabular}{llll}
\hline Complexes & $\begin{array}{l}\mathrm{E}_{1 / 2} \\
\left(\mathrm{~V}_{\text {SCE }}\right)\end{array}$ & $\begin{array}{l}\mathrm{E}_{1 / 2} \text { in solution } \\
\left(\mathrm{V}_{\text {SCE }}\right)\end{array}$ & $\begin{array}{l}\text { Volume concentration }^{\mathrm{a}} \\
\left(\mathrm{mol} \mathrm{cm}^{-3}\right) \times 10^{8}\end{array}$ \\
\hline $\mathbf{1}$ & 0.52 & 0.28 & 1.4 \\
$\mathbf{2}$ & 0.54 & 0.27 & 1.8 \\
$\mathbf{3}$ & 0.60 & 0.31 & 0.6 \\
$\mathbf{4}$ & 0.62 & 0.29 & 1.2 \\
\hline
\end{tabular}

${ }^{\mathrm{a}}$ An error around 5\% was estimated from two samples of $1 \mathrm{~cm}^{3}$ taken in a same grafted felt. 
Table 2: Catalytic activity of the immobilized copper (II) complexes 1-4

\begin{tabular}{llllll}
\hline & Blank & Complex 1 & Complex 2 & Complex 3 & Complex 4 \\
\hline Rate / & $0.2[22]$ & 6.46 & 7.83 & 10.50 & 18.90
\end{tabular}

$\times 10^{8} \mathrm{~mol}^{-1} \mathrm{~L} \mathrm{~s}^{-1}$

Scheme 1

(2)

Scheme 2

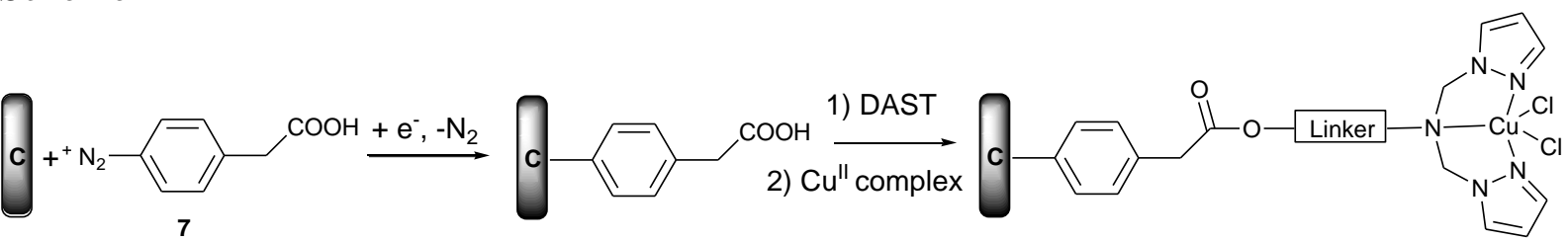

Scheme 3
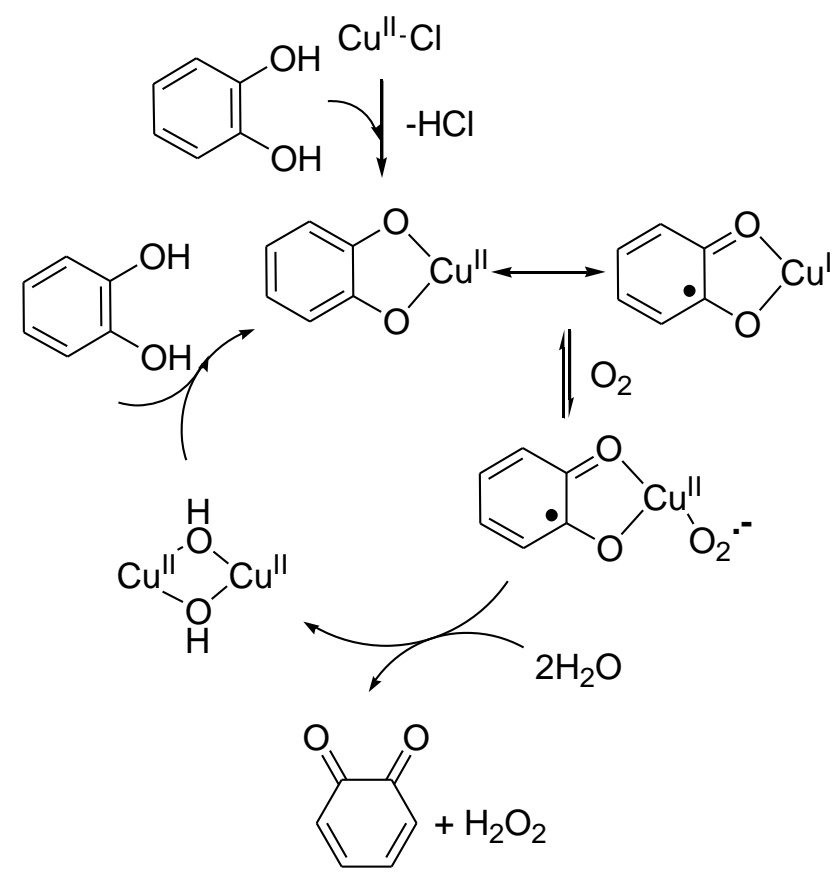
Figure captions

Figure 1: Structure of the ligands L1-4 with the corresponding complexes 1-4.

Figure 2: Cyclic voltammograms at graphite felt electrode of $\mathrm{K}_{3}\left[\mathrm{Fe}(\mathrm{CN})_{6}\right]$ in $0.5 \mathrm{M}$ phosphate buffer $\mathrm{pH}=7$ before - and after - - - grafting of 4-carboxymethyl-benzenediazonium salts 6 . Scan rate $0.1 \mathrm{~V} \mathrm{~s}^{-1}$.

Figure 3 : Cyclic voltammograms of freshly immobilized copper complexes 1-4, and 2 after one week air exposure (----), in acetonitrile $+0.1 \mathrm{M} \mathrm{Bu}_{4} \mathrm{NPF}_{6}$. Scan rate $0.02 \mathrm{~V} \mathrm{~s}^{-1}$. Only the bottom of the wave (e. $g$. hatched area) was considered for calculation of the surface concentration using the Faraday law.

Figure 4: Plot of absorbance vs. time for the oxidation of 3,5-di-tert-butylcatechol performed at $25^{\circ} \mathrm{C}$ in $\mathrm{MeOH}$ and catalyzed by the immobilized complexes $1 \square, 2 \triangle, 3 \circ$ and $4 \bullet$. A blank was performed with graphite felt modified by 4-carboxymethyl-benzenediazonium salts $7 \boldsymbol{\nabla}$. Error bars are based on two reproducibility measurements.

Figure 5: Plot of absorbance vs. time for the oxidation of 3,5-di-tert-butylcatechol performed at $25^{\circ} \mathrm{C}$ in $\mathrm{MeOH}$ and catalyzed by the immobilized complexes $\mathbf{3}$ (left) and $\mathbf{4}$ (right) used immediately after their preparation ( $\square$ ) or after several days of air exposure (०).

Figure 1

\begin{tabular}{lll}
\hline $\mathrm{R}$ & Ligand & Complex \\
\hline $\mathrm{C}_{2} \mathrm{H}_{4} \mathrm{OH}$ & $\mathbf{L}_{1}$ & {$\left[\mathrm{Cu}\left(\mathrm{L}_{1}\right) \mathrm{Cl}\right] \mathrm{Cl} \mathrm{1}$} \\
$\mathrm{C}_{6} \mathrm{H}_{12} \mathrm{OH}$ & $\mathbf{L}_{2}$ & {$\left[\mathrm{Cu}\left(\mathrm{L}_{2}\right) \mathrm{Cl}\right] \mathrm{Cl} \mathbf{2}$} \\
$\mathrm{C}_{2} \mathrm{H}_{4} \mathrm{OC}_{2} \mathrm{H}_{4} \mathrm{OH}$ & $\mathbf{L}_{3}$ & {$\left[\mathrm{Cu}\left(\mathrm{L}_{3}\right) \mathrm{Cl}\right] \mathrm{Cl} \mathbf{3}$} \\
$\left(\mathrm{C}_{2} \mathrm{H}_{4} \mathrm{O}\right)_{3} \mathrm{C}_{2} \mathrm{H}_{4} \mathrm{OH}$ & $\mathbf{L}_{4}$ & {$\left[\mathrm{Cu}\left(\mathrm{L}_{4}\right) \mathrm{Cl}\right] \mathrm{Cl} \mathbf{4}$} \\
\hline
\end{tabular}


Figure 2

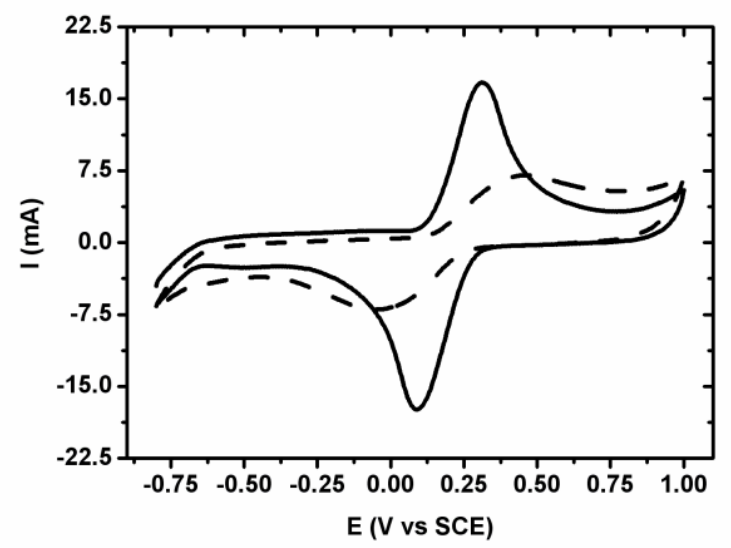

Figure 3
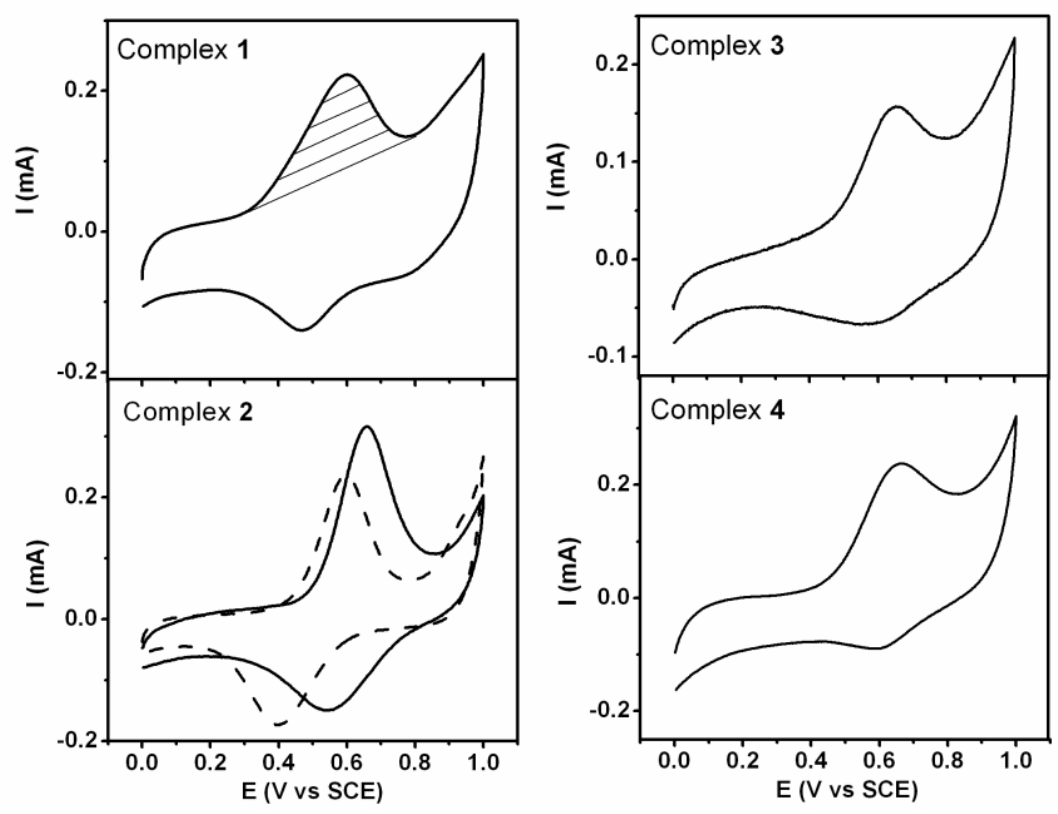
Figure 4

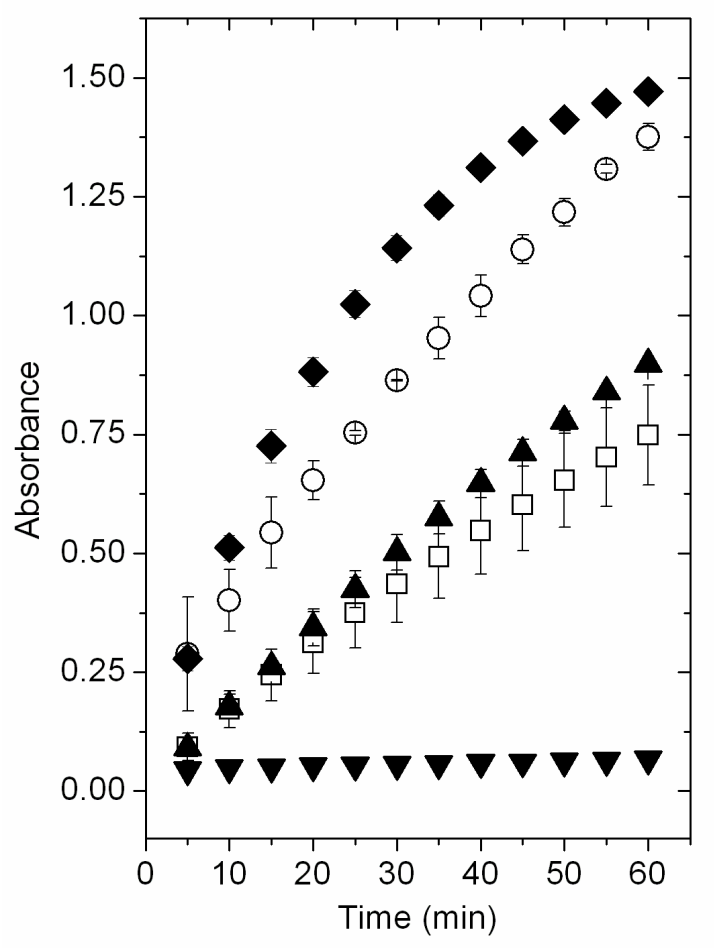


Figure 5
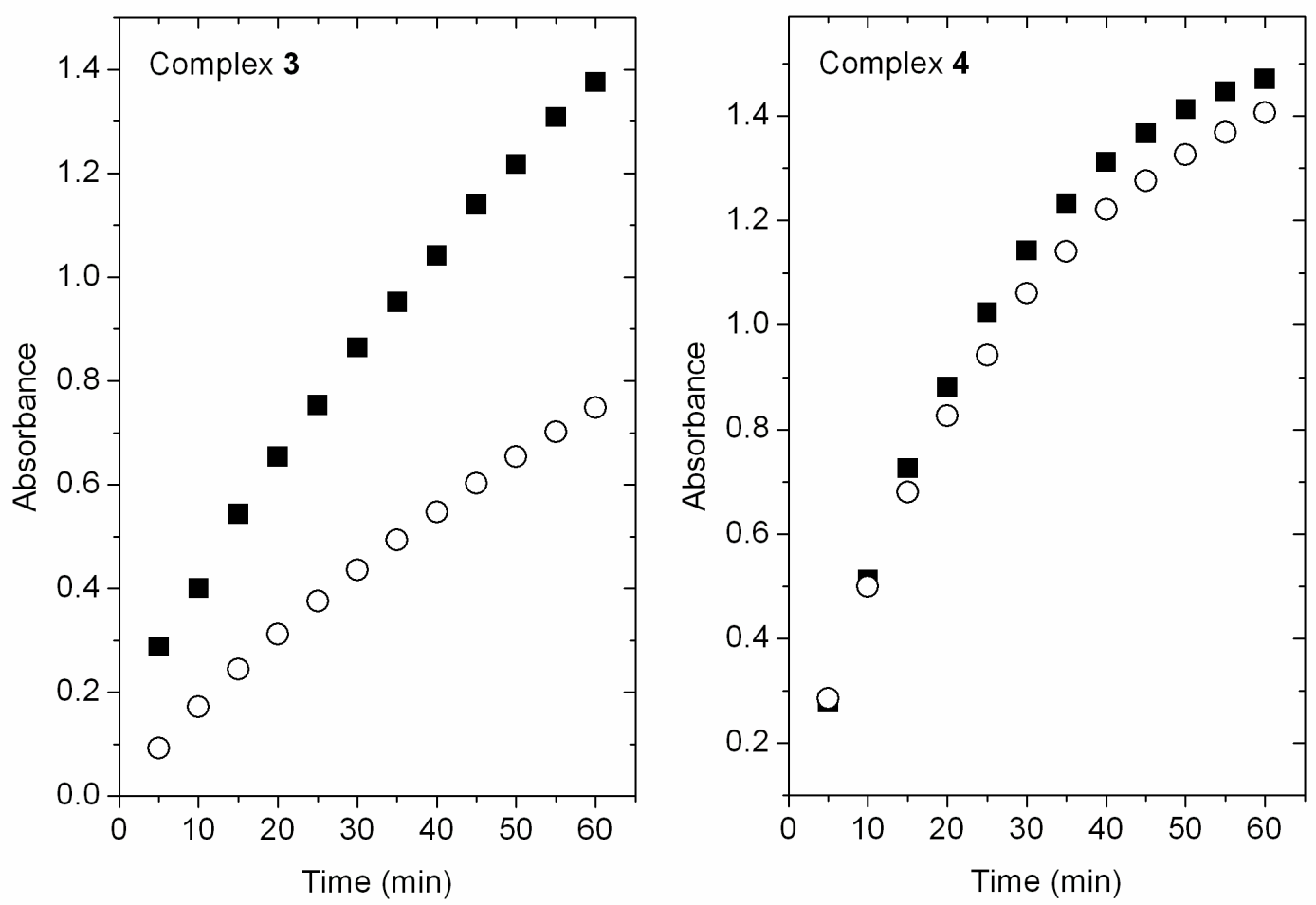